\title{
Resolusi Konflik Perkawinan Melalui Mediasi Dalam Perkara Perceraian Di Pengadilan Agama Manado
}

\author{
Ridwan Jamal (ridwanjamalstain@gmail.com) \\ Fakultas Ekonomi dan Bisnis Isalam, Institut Agama Islam Negeri Manado, Sulawesi Utara, \\ Indonesia
}

\begin{abstract}
This research aims to (1) describe and explore the implementation of marital conflict resolution through mediation in divorce cases in Manado Religious Courts, (2) to describe and explore the model of marriage conflict resolution through mediation in divorce cases in Religious Court of Manado, and (3) to describe and explanate the factors that become the obstacle of failure of marriage conflict resolution through mediation in divorce case in Religious Court of Manado. This research is a case study that is descriptive qualitative. This research was conducted in Manado city with the object of research is the office of Religious Court of Manado. The research informant is the leader of the Chairman and Vice Chairman of the Religious Court of Manado, the mediator (profession) on the implementation of mediation of divorce dispute, and the judge at the office of Manado Religious Court numbering 4 judges. The research data was collected by observation, interview, and documentation. The collected data is analyzed by flow model. The findings of the research indicate that (1) the implementation of marriage conflict resolution through mediation in divorce cases in Manado Religion Court is conducted by following the judicial regulations as stipulated in Supreme Court regulation concerning mediation procedure in religious court with pramediation, mediation and postmediation stage, (2) model The confirmation by the parties is mediated by the mediator of the judge, while the non-judicial mediator has not been practiced, and (3) the constraints to the failure of the marriage conflict resolution through mediation in the divorce case in the Manado Religion Court are divided into two main factors: (1) the general factors of the law, the additional factor of the number of judges, the factor of society is the low level of public knowledge, the lack of mediation facilities and
\end{abstract}


infrastructure, and the cultural factors, and (2) the plaintiff factor, the mediator, the mediation atmosphere, and the litigants.

Keynotes: Resolutionconflict, marriage, mediation, divorce.

\begin{abstract}
ABSTRAK
Penelitian ini bertujuan (1) mendeskripsikan dan mengeksplanasi pelaksanaan resolusi konflik perkawinan melalui mediasi dalam perkara perceraian di Pengadilan Agama Manado, (2) mendeskripsikan dan mengeksplanasi model resolusi konflik perkawinan melalui mediasi dalam perkara perceraian di Pengadilan Agama Manado, dan (3) mendeskripsikan dan mengeksplanasi faktor-faktor yang menjadi kendala gagalnya resolusi konflik perkawinan melalui mediasi dalam perkara perceraian di Pengadilan Agama Manado. Penelitian ini merupakan jenis studi kasus yang bersifat deskriptif kualitatif. Penelitian ini dilaksanakan di kota Manado dengan objek penelitian ialah kantor Pengadilan Agama Manado. Informan penelitian ialah unsur pimpinan Ketua dan Wakil Ketua Pengadilan Agama Manado, mediator (profesi) pada pelaksanaan mediasi sengketa perceraian, dan hakim pada kantor Pengadilan Agama Manado yang berjumlah 4 orang hakim. Data penelitian dikumpulkan dengan teknik observasi, wawancara, dan dokumentasi. Data yang terkumpul dianalisis dengan model alir (flow model). Temuan penelitian menunjukkan bahwa (1) pelaksanaan resolusi konflik perkawinan melalui mediasi dalam perkara perceraian di Pengadilan Agama Manado dilakukan dengan mengikuti kaidah hukum yang tertuang dalam Peraturan Mahkamah Agung tentang Prosedur Mediasi di Pengadilan Agama dengan tahapan pramediasi, mediasi, dan pascamediasi, (2) model resolusi konflik perkawinan melalui mediasi dalam perkara perceraian di Pengadilan Agama Manado didasarkan pada konsensus oleh para pihak dengan dimediasi oleh mediator hakim, sedangkan mediator non hakim belum dipraktekkan, dan (3) faktor-faktor kendala gagalnya resolusi konflik perkawinan melalui mediasi dalam perkara perceraian di Pengadilan Agama Manado terbagi dalam dua faktor kendala utama, yaitu: (1) kendala umum terdiri dari:
\end{abstract}


faktor kaidah hukum, faktor keterbatasan jumlah hakim, faktor masyarakat yaitu rendahnya pengetahuan masyarakat, faktor sarana dan prasarana mediasi yang minim, dan faktor kebudayaan, dan (2) kendala khusus terdiri dari faktor penggugat, mediator, suasana mediasi, dan para pihak yang berperkara.

Kata Kunci: Resolusi konflik, perkawinan, mediasi, perceraian. 


\section{PENDAHULUAN}

Coser (dalam Anogara, 1992) menyatakan bahwa konflik selalu ada di tempat kehidupan bersama, bahkan dalam hubungan yang sempurna sekalipun konflik tidak dapat dielakkan dan konflik semakin meningkat dalam hubungan yang serius. Setiap saat dimana terdapat dua orang atau dua kelompok yang akan mengambil keputusan mempunyai potensi untuk menimbulkan suatu konflik. Sumber konflik dapat berasal dari kontak interaksi ketika dua pihak bersaing atau salah satu pihak mencoba untuk mengeksploitasi pihak lain (Brigham dalam Dewi \& Basti, 1991:43).

Demikian pula halnya dengan kehidupan perkawinan. Kebahagiaan merupakan hal utama yang menjadi tujuan dan sangat diharapkan dari sebuah perkawinan. Namun untuk mencapai suatu kebahagiaan perkawinan bukanlah sesuatu hal yang mudah karena kebahagiaan perkawinan akan tercapai apabila pasangan suami istri memiliki kualitas interaksi perkawinan yang tinggi. Dalam suatu perkawinan terkadang apa yang diharapkan oleh masing-masing individu tidak sesuai dengan kenyataannya setelah individu tersebut menjalani bahtera rumah tangga. Perkawinan menuntut adanya perubahan gaya hidup, menuntut adanya penyesuaian diri terhadap tuntutan peran dan tanggung jawab baru baik dari suami maupun istri. Ketidakmampuan untuk melakukan tuntutan-tuntutan tersebut tidak jarang menimbulkan pertentangan, perselisihan dan bahkan berakhir dengan perceraian.

Perselisihan, pertentangan dan konflik dalam suatu rumah tangga merupakan sesuatu yang terkadang tidak bisa dihindari, tetapi harus dihadapi. Hal ini karena dalam suatu perkawinan terdapat penyatuan dua pribadi yang unik dengan membawa sistem keyakinan masing-masing berdasar latar belakang budaya serta pengalaman yang berbeda-beda. Perbedaan yang ada tersebut perlu disesuaikan satu sama lain untuk membentuk sistem keyakinan baru bagi keluarga mereka. Proses inilah yang seringkali menimbulkan ketegangan, ditambah lagi dengan sejumlah perubahan yang harus mereka hadapi, misalnya perubahan kondisi hidup, perubahan kebiasaan atau perubahan kegiatan sosial (Dewi \& Basti, 1991:43).

$\overline{\text { Resolusi Konflik Perkawinan Melalui Mediasi Dalam Perkara Perceraian Di Pengadilan }}$ Agama Manado

Ridwan Jamal 
Eskalasi konflik yang makin tajam dalam keluarga tidak jarang berujung pada tindakan perceraian. Berkaitan dengan perceraian, Undang-Undang Perkawinan memiliki asas untuk mempersulit perceraian. Asas mempersulit perceraian ini dapat dilihat dari pasal 39 ayat (1) Undang-Undang Nomor 1 Tahun 1974 tentang Perkawinan menjelaskan "Perceraian hanya dapat dilakukan di depan Sidang Pengadilan setelah Pengadilan yang bersangkutan berusaha dan tidak berhasil mendamaikan kedua belah pihak". Adanya pasal 39 ayat (1) ini juga dilatarbelakangi oleh adanya proses perdamaian yang terdapat dalam pasal 130 Herziene Indonesisch Reglement (HIR) yang berbunyi, Jika pada hari yang ditentukan itu kedua belah pihak menghadap, maka pengadilan negeri, dengan perantara keduanya, akan mencoba memperdamaikan mereka itu.

Pada tahun 2002 Mahkamah Agung, proses perdamaian ini dikembangkan oleh Mahkamah Agung. Diawali dengan menerbitkan Surat Edaran Mahkamah Agung Nomor 1 Tahun 2002 (SEMA No 1 Tahun 2002), kemudian diubah menjadi Peraturan Mahkamah Agung Nomor 2 Tahun 2003 (Perma No 2 Tahun 2003), kembali diubah menjadi Peraturan Mahkamah Agung Nomor 1 Tahun 2008 Tentang Prosedur Mediasi di Pengadilan (Perma No 1 Tahun 2008), dan kemudian diubah kembali dengan Peraturan Mahkamah Agung Nomor 1 Tahun 2016 Tentang Prosedur Mediasi.

Sejak Perma No 1 Tahun 2008 itu, dalam hukum acara persidangan sengketa perceraian di Pengadilan Agama diwajibkan untuk menempuh mediasi. Mediasi ini merupakan upaya perdamaian atau resolusi konflik antara pihak suami dan pihak istri yang akan bercerai. Dengan kata lain, setelah adanya Perma Nomor 1 Tahun 2008, tahap mediasi ini wajib dilakukan kepada semua perkara perdata yang diajukan ke pengadilan tingkat pertama. Kewajiban menempuh mediasi pada pengadilan tingkat pertama oleh para pihak yang mengajukan perkara talak ataupun gugutan cerai ini dipertegas kembali dalam Perma Nomor 1 Tahun 2016.

Menurut Usman (2012:16), keuntungan tersebut antara lain, penyelesaian bersifat informal, yang menyelesaikan sengketa para pihak sendiri, jangka waktu penyelesaian 
pendek, biaya ringan, aturan pembuktian tidak perlu, proses penyelesaian bersifat konfidensial, hubungan para pihak bersifat kooperatif, komunikasi dan fokus penyelesaian, hasil yang dituju sama menang, dan bebas emosi dan dendam.

Bila dikaitkan dengan sengketa perceraian, mediasi memiliki manfaat khusus tersendiri. Menurut Manan (2006:164), dengan dicapainya upaya perdamaian antara suami istri dalam sengketa perceraian, tujuan perkawinan untuk membentuk rumah tangga yang bahagia dan kekal dapat dicapai karena keutuhan rumah tangga dapat diselamatkan dan kelanjutan pemeliharaan anak dapat dilaksanakan sebagaimana mestinya.

Mediasi merupakan proses perundingan pemecahan masalah dimana pihak luar yang tidak memihak (impartial) dan netral bekerja dengan pihak yang bersengketa untuk membantu mereka memperoleh kesepakatan perjanjian dengan memuaskan. Berbeda dengan hakim atau arbiter, mediator tidak mempunyai wewenang untuk memutuskan sengketa antara para pihak. Namun dalam hal ini para pihak menguasakan kepada mediator untuk membantu mereka menyelesaikan masalah di antara mereka. Asumsinya bahwa pihak ketiga akan mampu mengubah kekuatan dan dinamika sosial hubungan konflik dengan cara mempengaruhi tingkah laku pribadi para pihak dengan memberikan pengetahuan atau informasi yang lebih efektif. Dengan demikian, mediator dapat membantu para pihak untuk menyelesaikan persoalan-persoalan yang dipersengketakan (Goodpaster, 1993:201).

Mediasi dalam ajaran Islam dikenal dengan istilah islah. Islah adalah memutuskan suatu persengketaan, sedangkan menurut istilah syarak islah adalah suatu akad dengan maksud mengakhiri suatu persengketaan antara dua orang. Yang dimaksud di sini adalah mengakhiri suatu persengketaan dengan perdamaian karena Allah mencintai perdamaian (alȚarablīsī, t.t.:123). Pertentangan itu apabila berkepanjangan akan mendatangkan kehancuran. Oleh karena itu, islah mencegah hal-hal yang menyebabkan kehancuran dan menghilangkan hal-hal yang membangkitkan fitnah dan pertentangan. Mediasi khususnya dalam bidang perkawinan Islam dilakukan dengan bantuan hakamayn yang ditunjuk dari kerabat kedua belah pihak sebagaimana surah al-Nisā' [4] ayat 35. Ayat ini menjelaskan bahwa peran dan 
fungsi hakam dalam peradilan Islam artinya juru damai, yakni juru damai yang dikirim oleh dua belah pihak suami dan istri apabila terjadi perselisihan antara keduanya, tanpa diketahui keadaan siapa yang benar dan siapa yang salah di antara kedua suami istri tersebut (Abidin, 1999:189).

Pengangkatan hakamayn dalam penyelesaian sengketa perkawinan khususnya shiqāq juga telah diintegrasikan dalam proses beracara di Pengadilan Agama. Hal itu dibuktikan dengan diaturnya masalah pengangkatan hakamayn dalam Kompilasi Hukum Islam Pasal 76 Ayat (2). Namun, pada kenyataannya jarang sekali atau hampir tidak ada hakim mengangkat hakamayn sebagaimana maksud pasal tersebut di atas. Secara yuridis formal Undang-Undang Nomor 7 Tahun 1989 yang telah diubah dengan Undang-Undang Nomor 3 Tahun 2006, Pasal 76 telah menetapkan keberadaan hakam dalam perkara perceraian yang eksistensinya sama dengan mediator. Demikian halnya secara normatif, mediator atau hakam sudah dikenal sejak awal pembentukan hukum Islam, baik dalam perkara perceraian secara khusus maupun perkara perdata atau bentuk perkara lainnya.

Makamah Agung Republik Indonesia melalui Peraturan Mahkamah Agung (Perma) Nomor 01 Tahun 2008 tentang Prosedur Mediasi di Pengadilan telah mengintegrasikan mediasi ke dalam proses beracara di pengadilan sebagai salah satu instrumen untuk mengatasi penumpukan perkara. Mediasi ini diterapkan sebagai bagian acara dalam perkara perdata di lingkungan peradilan agama dan peradilan umum. Bagi lingkungan peradilan agama sendiri, kehadiran seorang mediator dalam suatu perkara tampaknya tidak dianggap sebagai sebuah hal yang baru. Selain itu, penyelesaian sengketa secara damai juga dikenal dalam hukum Islam, dimana Islam mengajarkan agar pihak-pihak yang bersengketa melakukan perdamaian (QS al-Nisā' ayat 128). Islam selalu menyuruh menyelesaikan setiap persengketaan melalui islah. Dengan demikian, mediasi dan konsiliasi adalah jalan untuk mendapatkan keadilan yang ideal dalam menyelesaikan sengketa (Luney dalam Salamah, 2013).

Namun kenyataan di lapangan menunjukkan bahwa proses mediasi dalam perkara perceraian di Pengadilan Agama yang hakikatnya ialah mendamaikan suami istri yang 
hendak bercerai terkesan hanya prosedur beracara dalam sidang perceraian. Faktanya, angka perceraian setiap tahunnya terus meningkat. Hal ini bisa dilihat dari seringnya masalah tersebut menjadi berita hangat di media massa, baik lokal maupun nasional. Tampaknya masalah ini bukan hanya terjadi pada keluarga dari kelas tertentu, namun juga menimpa keluarga dari semua lapisan/kelas sosial. Data yang dilansir Pikiran Rakyat (2015) menunjukkan bahwa angka perceraian di Indonesia sangat fantastis. Dipaparkan bahwa tahun 2009 menikah sebanyak 2.162.268 kejadian dan cerai 216.286 kejadian, tahun 2010 menikah 2.207.364 kejadian dan cerai 285.184 kejadian, tahun 2011 menikah 2.319.821 kejadian dan cerai 258.119 kejadian, tahun 2012 menikah 2.291.265 kejadian dan cerai 372.577 kejadian, tahun 2013 menikah 2.218.130 kejadian, cerai 324.527 kejadian.

Berdasarkan data di atas, jika sampel data diambil untuk tahun 2012 dan 2013, misalnya, jika diambil tengahnya, maka angka perceraian di dua tahun itu sekitar 350.000 kasus. Berarti dalam satu hari rata-rata terjadi 959 kasus perceraian, atau 40 perceraian setiap jam. Kondisi ini jelas sangat memprihatinkan.

Dalam konteks lokal kota Manado misalnya, pada tahun 2012, sebanyak 245 perkara yang diperoses di Pengadilan Agama Manado. Pada tahun 2013 periode Januari sampai Oktober, data Pengadilan Agama Manado menunjukkan sebanyak 255 berkas perkara gugatan dan sebanyak 12 perkara merupakan permohonan (penetapan ahli waris, itsbat/wali nikah, dispensasi kawin, dan pengangkatan anak). Dari 255 perkara gugatan, sebanyak 243 merupakan perkara gugatan cerai yang terdiri atas 167 cerai gugat dan 76 cerai talak.

Untuk tahun 2014 dan 2015, data di Pengadilan Agama menunujukkan sebanyak 329 perkara perceraian, di mana 104 perkara cerai talak dan sebanyak 225 cerai gugat. Yang dimediasi sebanyak 106, berhasil dimediasi sebanyak 6 perkara, dan yang tidak layak dimediasi 217 perakara. Untuk tahun 2015 jumlah perkara peceraian sebanyak 356, dimana 102 cerai talak dan 254 cerai gugat. Yang dimediasi sebanyak 102, yang berhasil dimediasi sebanyak 4 perkara, dan yang tidak layak dimediasi sebanyak 250 perkara (Pengadilan Agama Manado, 2016).

$\overline{\text { Resolusi Konflik Perkawinan Melalui Mediasi Dalam Perkara Perceraian Di Pengadilan }}$ Agama Manado

Ridwan Jamal 
Data di atas menunjukkan bahwa perkawinan di Indonesia dan di kota Manado khususnya masih cukup rentang dengan konflik. Dan, dari 208 perkara yang dimediasi untuk tahun 2014 dan 2015 hanya 10 perkara yang berhasil dimediasi atau hanya 4,81\% dari total perkara yang demediasi. Oleh karena itu menarik untuk dikaji resolusi konflik perkawinan melalui mediasi dalam perkara perceraian di Pengadilan Agama.

\section{DESKRIPSI SINGKAT SITUS PENELITIAN}

Pengadilan Agama Manado merupakan organisasi kolegial yang terdiri dari unsur pimpinan, unsur pelaksana, dan unsur pembantu pimpinan yang di dalamnya mencakup unit kepaniteraan dan unit kesekretariatan.

Pada Pasal 1 Undang-Undang Nomor 50 Tahun 2009 tentang perubahan kedua atas Undang-Undang Nomor 7 Tahun 1989 tentang Peradilan Agama, tercantum bahwa tugas dan kewenangan Pengadilan Agama adalah menerima, memeriksa memutus, dan menyelesaikan perkara di tingkat pertama antara orang-orang beragama Islam di bidang Perkawinan, Waris, Wasiat, Hibah, Wakaf, Zakat, Infaq, Shadoqah, dan Ekonomi Syari'ah.

Dalam melaksanakan tugasnya sebagaimana kewenangan Pengadilan Agama sebagaimana dikemukakan di atas, Pengadilan Agama Manado membagi tugas para pegawai sebagai berikut (Data Dokumentatif berumber pada bagian kesekretariatan Pengadilan Agama Manado):

\section{UNSUR PIMPINAN}

Unsur pimpinan terdiri atas Ketua dan Wakil Ketua yang bertugas dan bertanggung jawab atas terselenggaranya peradilan dengan baik, menjaga terpeliharanya citra dan wibawa Pengadilan Agama serta bertanggung jawab atas terselenggaranya administrasi umum Pengadilan Agama dengan tertib, dan melakukan dan menjaga terpeliharanya hubungan antar instansi, baik sektoral maupun lintas sektoral.

$\overline{R e s o l u s i}$ Konflik Perkawinan Melalui Mediasi Dalam Perkara Perceraian Di Pengadilan Agama Manado

Ridwan Jamal 
Panitera, yang bertugas dan bertanggung jawab melaksanakan pemberian dukungan di bidang teknis dan administrasi perkara serta menyelesaikan surat-surat yang berkaitan dengan perkara berdasarkan peraturan Mahkamah Agung RI Nomor 7 Tahun 2015.

Sekretaris, yang bertugas dan bertanggung jawab melaksanakan pemberian dukungan di bidang administrasi, organisasi, keuanganm sumber daya manusia, serta sarana dan prasarana di lingkungan Pengadilan Agama Manado berdasarkan peraturan Mahkamah Agung RI Nomor 7 Tahun 2015.

\section{UNSUR PELAKSANA}

Unsur ini adalah unsur yang bertanggung jawab untuk melaksanakan tugas pokok Pengadilan Agama dalam fungsi mengadili yaitu memeriksa, memutus dan menyelesaikan perkara yang diajukan kepada Pengadilan Agama. Hal ini dilaksanakan oleh hakim dan dibantu oleh Panitera/ Panitera Pengganti Pengadilan Agama Manado, sebagaimana dalam uraian di bawah ini:

\section{HAKIM}

Hakim bertugas memeriksa dan mengadili memutus dan menyelesaikan setiap perkara yang diberikan/disarankan kepadanya berdasarkan penetapan Majelis Hakim. Di Pengadilan Agama Manado, hakim terdiri atas 4 orang, yaitu (1) Djufri Bobihu, S.Ag., S.H, (2) Drs. Anis Ismail, (3) Drs. Rahmat M.H., dan (4) Drs. Burhanudin Mokodompit, M.H.

\section{PANITERA/PANITERA PENGGANTI}

Panitera/Panitera Pengganti bertugas membantu hakim/majelis hakim dengan menghadiri dan mencatat jalannya sidang serta membuat berita acara semua peristiwa hukum yang terjadi dalam persidangan perkara yang ditangani hakim/majelis hakim tersebut. Di Pengadilan Agama Manado, Panitera Pengganti terdiri atas 6 orang, yaitu (1) Rahmawati, S, 
(2) Zuhaeda Selong SH, (3) Hanafie Pulukadang, S.Ag, (4) Muhammad Adil, S.Ag, (5) Husain Lahilote, S.Ag, dan (6) Ulfa Jaba, S.Ag.

\section{JURUSITA/JURUSITA PENGGANTI}

Jurusita/Jurusita Pengganti bertugas melakukan semua perintah yang berhubungan dengan kejurusitaan yang diberikan Ketua Pengadilan atau Hakim/Majelis Hakim yang dikoordinasikan oleh Panitera di dalam wilayah/hukum Pengadian Agama Manado. Di Pengadilan Agama Manado, Jurusita Pengganti terdiri atas 9 orang, yaitu (1) Djufrianto Antu, (2) Djasida Doliap, S.HI, (3) Herman Pomolango, (4) Hamdan Basjir, (5) Husain Permata, (6) Sudriman Sumohardjo, (7) Satri Padju, (8) Andi Candra Mokolintad, dan (9) Purwanto.

\section{UNSUR PEMBANTU PIMPINAN}

Unsur pembantu pimpinan adalah unsur yang bertanggung jawab untuk melaksanakan tugas secara operasional dalam kegiatan yang bersifat sebagai unsur penunjang dan pendukung pelayanan administratif atas pelaksanaan tugas pokok Pengadilan Agama, di bawah kewenangan Panitera Pengadilan Agama Manado. Adapun unit penunjang dan pendukung untuk melaksanakan tugas tersebut sebagaimana diuraikan di bawah ini:

\section{KEPANITERAAN}

Kepaniteraan merupakan unit kerja yang menunjang pelaksanaan tugas pokok dan fungsi pengadilan agama dalam hal pengelolaan administrasi perkara baik sebelum persidangan maupun setelah persidangan. Untuk unit kepaniteraan di bawah Wakil Panitera (Hj. Rusna Poli, SH, MH) dibantu oleh tiga Panitera Muda (Parimud) yaitu (1) Panitera Muda Gugatan (Masita Mayang, S.Ag. yang menangani perkara-perkara gugatan (2) Panitera Muda Permohonan (Hasna Bin Nurdin Harus, SH) yang menangani perkara-perkara permohonan, dan (3) Panitera Muda Hukum (Rosna Ali, S.Ag) yang menangani masalah kearsipan 
perkara, laporan perkara dan perkara-perkara yang dimintakan upaya hukum lainnya seperti banding, kasasi, dan peninjuan kembali (PK).

\section{KESEKRETARIATAN}

Kesekretariatan merupakan suatu unit kerja yang berfungsi sebagai usaha Pengadilan Agama dalam mengelola manajemen perkantoran pada umumnya, dan pada khususnya menangani administrasi umum dan keuangan administrasi kepegawaian dan ortala, dan administrasi Perencanaan, IT, dan Pelaporan.

Untuk unit kerja sekretariat dibantu oleh tugas Kepala Sub Bagian yaitu (1) Kasub pelaksanaan urusan surat menyurat, arsip, perlengkapan rumah tangga, keamanan, keprotokolan, perpustkaan serta pengelolaan keuangan, (2) Kasub Bagian Kepegawaian Organisani dan Tata Laksana (Dra. Zulianti Bakari) yang bertugas kepegawaian, penataan organisasi dan tata laksana dan (3) Kasub Bagian Perencanaan, IT, dan Pelaporan (Ramlia Hamzah, S.Ag) yang bertanggung jawab atas pelaksanaan penyiapan bahan pelaksanaan program dan anggaran, pengelolaan teknologi informasi, dan statistik, serta pelaksanaan pemantauan evaluasi dan dokumentasi serta pelaporan.

\section{PELAKSANAAN RESOLUSI KONFLIK PERKAWINAN MELALUI MEDIASI DALAM PERKARA PERCERAIAN}

Pelaksanaan resolusi konflik perkawinan melalui mediasi dalam perkara perceraian di Pengadilan Agama Manado didasarkan pada norma hukum yang ada yaitu Peraturan Mahkamah Agung RI Nomor Nomor 1 Tahun 2008 dan telah direvisi dengan Perma Nomor 1 Tahun 2016. Sejak dikeluarkannya Peraturan Mahkamah Agung Nomor 2 Tahun 2003 hingga Perma Nomor 1 Tahun 2008 dan Perma Nomor 1 Tahun 2016 tentang Prosedur Mediasi di Pengadilan Agama tersebut berimplikasi terhadap susunan proses beracara di Pengadilan Agama. Ada penambahan bagian yang bernama mediasi, dimana penambahan ini terletak 
setelah pembukaan sidang pertama. Perubahan ini berlaku untuk semua kewenangan yang dimiliki pengadilan agama tidak terkecuali perkara perceraian.

Kewajiban para pihak untuk menempuh prosedur mediasi pada hari sidang pertama yang dihadiri kedua belah pihak dan kewajiban para pihak yang berperkara agar lebih dahulu menempuh mediasi ini tercermin sejak Perma RI Nomor 2 Tahun 2003, Perma RI Nomor 1 Tahun 2008, hingga Perma RI Nomor 1 Tahun 2016.

Selain itu, Peraturan Mahkamah Agung Nomor 1 Tahun 2008 maupun Perma RI Nomor 1 Tahun 2016 juga berlaku tidak hanya untuk pengadilan agama saja, akan tetapi juga berlaku untuk pengadilan umum seperti ketentuan yang terdapat dalam Pasal 4 Peraturan Mahkamah Agung Republik Indonesia Nomor 01 Tahun 2008 yang menyatakan kecuali perkara yang diselesaikan melalui prosedur pengadilan niaga, pengadilan hubungan industrial, keberatan atas putusan Badan Penyelesaian Sengketa Konsumen, dan keberatan atas putusan Komisi Pengawas Persaingan Usaha, semua sengketa perdata yang diajukan ke Pengadilan Tingkat Pertama wajib lebih dahulu diupayakan penyelesaian melalui perdamaian dengan bantuan mediator.

Jadi dapat disimpulkan bahwa berdasarkan kaidah hukum yang ada sejak Perma Nomor 2 Tahun 2003, Perma Nomor 1 Tahun 2008, hingga Perma Nomor 1 Tahun 2016 telah menetapkan kaidah hukum dalam bermediasi bagi pasangan suami istri yang mendaftarkan perkara di Pengadilan Agama, yaitu:

a. Kewajiban para pihak menempuh mediasi;

b. Penegak hukum (hakim) berkewajiban untuk mewajibkan para pihak menempuh mediasi;

c. Penyelesaian sengketa secara damai tanpa merugikan salah satu pihak; dan

d. Pihak yang tidak beritikad baik untuk melakukan mediasi dihukum denda/membayar biaya perkara.

Dalam pelaksanaan resolusi konflik perceraian melalui mediasi di Pengadilan Agama Manado, unsur-unsur yang terlibat adalah:

$\overline{R e s o l u s i}$ Konflik Perkawinan Melalui Mediasi Dalam Perkara Perceraian Di Pengadilan Agama Manado

Ridwan Jamal 
a. Pihak Pertama

Pihak pertama di sini adalah pihak yang mengajukan permohonan atau gugatan. Jika perkara merupakan cerai gugat maka pihak pertama di sini adalah pihak perempuan (istri), sementara itu jika perkara merupakan cerai talak maka pihak pertama merupakan laki-laki (suami).

b. Pihak Kedua

Pihak kedua adalah pihak yang dipanggil oleh Pengadilan Agama karena permohonan/gugatan yang diajukan oleh pihak pertama. Jika perkara merupakan cerai gugat, maka pihak pertama di sini adalah pihak laki-laki (suami) sementara itu jika perkara merupakan cerai talak, maka pihak pertama merupakan pihak perempuan (istri).

c. Pihak Ketiga yang Netral (Mediator)

Mediator adalah pihak netral yang membantu pihak dalam proses perundingan guna mencari berbagai kemungkinan penyelesaian sengketa tanpa menggunakan cara memutus atau memaksakan sebuah penyelesaian.

Adapun syarat seorang mediator adalah setiap mediator harus mendapatkan sertifikat dari lembaga yang telah ditunjuk dan diakreditasi oleh Mahkamah Agung (MA) setelah mengikuti pelatihan oleh lembaga tersebut. Kecuali jika dalam wilayah pengadilan yang bersangkutan tidak ada mediator yang bersertifikat, semua hakim pada pengadilan yang bersangkutan dapat ditempatkan dalam daftar mediator. Jika pada pengadilan yang sama tidak terdapat hakim bukan pemeriksa perkara yang bersetifikat, maka hakim pemeriksa pokok perkara dengan atau tanpa sertifikat yang ditunjuk oleh ketua majelis hakim wajib menjalankan fungsi mediator.

Di Pengadilan Agama Manado, sudah ada hakim yang bersertifikat mediator. Sertifikat tersebut dikeluarkan oleh Pengadilan Tinggi Agama ataupun yang dikeluarkan oleh Mahkamah Agung Republik Indonesia. Resolusi konflik dalam perkara perceraian melalui mediasi di Pengadilan Agama Manado selama ini dilakukan oleh hakim yang telah bersertifikat (Wawancara dengan Wakil Ketua Pengadilan Agama Manado).

$\overline{R e s o l u s i}$ Konflik Perkawinan Melalui Mediasi Dalam Perkara Perceraian Di Pengadilan Agama Manado

Ridwan Jamal 
Dalam Pasal 5 Peraturan Mahkamah Agung Nomor 1 Tahun 2008 Tentang Prosedur Mediasi di Pengadilan disebutkan bahwa yang dapat menjadi mediator dalam sidang perkara perceraian ialah (1) mereka yang telah memiliki sertifikat mediator yang diperoleh setelah mengikuti pelatihan yang diselenggarakan oleh lembaga yang telah memperoleh akreditasi dari Mahkamah Agung RI dan (2) Jika dalam wilayah sebuah Pengadilan tidak ada hakim, advokat, akademisi hukum dan profesi bukan hukum yang bersertifikat mediator, hakim di lingkungan Pengadilan yang bersangkutan berwenang menjalankan fungsi mediator.

Proses mediasi di Pengadilan ini mempunyai implikasi hukum. Berikut ini akibat hukum yang ditimbulkan:

a. Jika tidak dilaksanakan mediasi, maka putusan yang dihasilkan batal demi hukum. Hal ini sesuai dengan Pasal 2 Ayat 4 Peraturan Mahkamah Agung Republik Indonesia Nomor 1 Tahun 2008 yang menyatakan bahwa tidak menempuh prosedur mediasi berdasarkan peraturan ini merupakan pelanggaran terhadap ketentuan pasal $140 \mathrm{HIR}$ dan atau pasal $154 \mathrm{RBg}$ yang mengakibatkan putusan batal demi hukum.

b. Jika telah dilaksanakan mediasi dan mencapai kesepakatan, seperti dalam pasal 17 Peraturan Mahkamah Agung Republik Indonesia Nomor 1 Tahun 2008, maka mediator:

1) Wajib merumuskan secara tertulis kesepakatan yang dicapai dan ditandatangani oleh para pihak dan mediator. Jika diwakili oleh kuasa hukum, maka para pihak wajib menyatakan secara tertulis persetujuan atas kesepakatan yang dicapai.

2) Wajib menghadap kembali kepada hakim pada hari sidang yang telah ditentukan untuk memberitahukan kesepakatan perdamaian.

3) Para pihak dapat mengajukan kesepakatan pedamaian kepada hakim untuk dikuatkan dalam bentuk akta perdamaian.

4) Jika para pihak menghendaki kesepakatan perdamaian dikuatkan dalam bentuk akta perdamaian, kesepakatan perdamaian harus memuat klausula pencabutan gugatan dan atau klausula yang menyatakan perkara telah selesai.

$\overline{R e s o l u s i}$ Konflik Perkawinan Melalui Mediasi Dalam Perkara Perceraian Di Pengadilan Agama Manado

Ridwan Jamal 
c. Jika telah dilaksanakan mediasi dan tidak mencapai kesepakatan, maka mediator wajib menyatkan secara tertulis bahwa proses mediasi telah gagal dan memberitahukan kegagalan kepada hakim. Hal ini sesuai dengan Pasal 18 Ayat 1 Peraturan Mahkamah Agung Republik Indonesia Nomor 1 Tahun 2008 yang menyatakan bahwa jika setelah batas waktu maksimal 40 (empat puluh) hari kerja sebagaimana dimaksud dalam pasal 13 ayat (3), para pihak tidak mampu menghasilkan kesepakatan atau karena sebab-sebab yang terkandung dalam pasal 14, mediator wajib menyatakan secara tertulis bahwa proses mediasi telah gagal dan memberitahukan kegagalan kepada hakim. Hakim segera melanjutkan pemeriksaan perkara sesuai ketentuan hukum acara yang berlaku. Hal ini sesuai dengan pasal 18 ayat 2 Peraturan Mahkamah Agung Republik Indonesia Nomor 1 Tahun 2008 yang menyatakan bahwa segera setelah menerima pemberitahuan tersebut, hakim melanjutkan pemeriksaan perkara sesuai ketentuan hukum acara yang berlaku.

Berdasarkan hasil observasi, wawancara, dan dokumentasi terkait tata cara mediasi dalam perkara perceraian di Pengadilan Agama Manado ditemukan urut-urutan proses mediasi sebagai berikut:

\section{PRAMEDIASI}

Setelah sampai di Pengadilan Agama, maka langkah-langkah selanjutnya yaitu sebagai berikut sesuai dengan petunjuk pendaftaran perkara yang terpasang di Pengadilan Agama Manado.

a. Pihak yang berpekara menyerahkan surat gugatan atau permohonan berikut persyaratan lainnya ke petugas meja pertama (ruang panitera)

b. Oleh petugas meja pertama ditentukan besar panjar biaya, perkara yang dituangkan dalam SKUM lalu diserahkan surat gugat atau permohonan dilengkapi SKUM kepada pihak yang berpekara.

c. Kemudian pihak yang berpekara menyerahkan surat gugatan atau permohonan beserta SKUM kepada pemegang kas.

$\overline{\text { Resolusi Konflik Perkawinan Melalui Mediasi Dalam Perkara Perceraian Di Pengadilan }}$ Agama Manado

Ridwan Jamal 
d. Lalu oleh pemegang kas SKUM diberi nomor perkara dan dibubuhi tanda tangan lalu diserahkan kepada pihak yang berpekara untuk dasar menyetorkan panjar biaya perkara kepada bank.

e. Oleh pihak yang berpekara mengusul slip setoran bank sesuai jumlah uang yang tertera dalam SKUM dan menyerahkan kepada petugas counter kas bank berikut uang panjar biaya perkara.

f. Lalu oleh petugas counter kas bank diserahkan 1 lembar SLIP setoran bank yang telah divalidasi kepada pihak yang berpekara.

g. Kemudian pihak yang berpekara menunjukkan bukti setoran bank dan menyerahkan SKUM untuk dibubuhi tanda lunas kepada pemegang kas.

h. Oleh pemegang kas diserahkan kepada pihak yang berpekara 1 lembar SKUM yang telah dibubuhi tanda lunas dan 1 eksemplar salinan surat permohonan/gugatan yang telah diberi tanda pendaftaran dan nomor perkara.

i. Juru sita pengganti akan datang ke alamat kedua pihak yang berpekara sesuai yang tercantum dalam surat gugatan/permohonan sesuai yang tercantum dalam surat gugatan/permohonan untuk melakukan pemanggilan sidang setelah ditetapkan hari sidangnya.

Setelah mendapatkan nomor register perkara dan kemudian dipanggil untuk sidang pertama, maka para pihak sebelum masuk ke gugatan/ permohonan maka dilakukan terlebih dahulu mediasi. Mediasi diawali dengan menjelaskan kepada pra pihak apa itu mediasi lalu menjelaskan terkait mediator apakah dari hakim atau dari orang yang ditunjuk oleh para pihak dalam hal ini harus sesuai dengan syarat mediator yang terdapat dalam Pasal 5 Peraturan Mahkamah Agung Republik Indonesia Nomor 1 Tahun 2008. Masih di dalam sidang pertama setelah memilih lalu menyepakati kapan para pihak melakukan mediasi. Lalu majelis hakim membuat surat penunjukkan terhadap hakim yang ditunjuk sebagai mediator untuk melaksanakan proses mediasi. 


\section{MEDIASI}

Proses mediasi dilakukan pada waktu yang telah disepakati oleh para pihak di ruang khusus mediasi. Proses mediasi dihadiri oleh mediator dan para pihak dengan mendengarkan dari para pihak untuk selanjutnya ditawarkan kemungkinan solusi yang mungkin diambil, jika perlu mediator dapat melakukan kaukus dengan mempersilahkan salah satu pihak untuk keluar ruangan terlebih dahulu dan di dalam ruang mediasi mediator berbicara pada salah satu pihak. Proses ini tidak berlangsung hanya satu waktu saja, akan tetapi tergantung pada kondisi suasana mediasi yang berbeda-beda. Maksimal waktu mediasi 40 hari sejak majelis hakim memutuskan untuk diadakannya mediasi sesuai dengan Peraturan Mahkamah Agung Republik Indonesia Nomor 1 Tahun 2008.

\section{PASCAMEDIASI}

Setelah proses mediasi berakhir ada kewajiban yang harus ditunaikan oleh para pihak dan juga mediator yaitu terkait para pihak harus menyampaikan kepada majelis hakim tentang hasil mediasi hal ini sesuai dengan pasal 17 ayat 4 Peraturan Mahkamah Agung Republik Indonesia nomor 1 Tahun 2008 sedangkan bagi majelis hakim harus melaloprkan secara tertulis hasil mediasi kepada majelis hakim sesuai kesepakatan para pihak yang telah ditandatangani oleh para pihak sebagaimana pasal 18 ayat 1 Peraturan Mahkamah Agung Republik Indonesia Nomor 1 Tahun 2008.

Apabila terjadi perdamaian tidak perlu dibuat akta perdamaian yang dikuatkan dengan putusan perdamaian, karena tidak mungkin dibuat suatu perjanjian/ketentuan yang melarang seseorang melakukan perbuatan tertentu, seperti melarang salah satu pihak meninggalkan tempat tinggal bersama, memerintahkan supaya tetap mencintai dan menyayangi, tetap setia, melarang supaya tidak mencaci maki dan lain sebagainya, karena hal-hal tersebut apabila diperjanjikan dalam suatu akta perdamaian dan kemudian dilanggar oleh salah satu pihak, maka akta perdamaian tersebut tidak dapat dieksekusi. Selain itu, akibat dari perbuatan itu dan tidak berbuatnya, tidak akan mengakibatkan terputusnya 
perkawinan, kecuali salah satu pihak mengajukan gugatan baru untuk perceraiannya. Hal ini juga untuk menghindari tidak diterimanya perkara (NO; NIet Ovankelijk Verklaat) berdasarkan azas nebis in idem (pasal 83 Undang-Undang Nomor 7 Tahun 1989 jo. pasal 32 Peraturan Pemerintah Nomor 9 Tahun 1975).

Berdasarkan pertimbangan sebagaimana tersebut di atas, maka kesepakatan yang ingin dicapai adalah kesepakatan untuk rukun dan damai, bukan kesepakatan untuk melakukan perceraian secara damai. Untuk itu dalam mewujudkan keinginan perdamaian dalam perkara perceraian adalah dengan jalan mencabut perkara tersebut. Artinya, secara normatif semua regulasi yang dikeluarkan oleh pemerintah terkait dengan pengadilan agama maupun prosedur mediasi di pengadilan agama terkait dengan perkara perceraian berorientasi pada resolusi konflik sehingga tidak terjadi perceraian. Hal ini merupakan bagian dari upaya pemerintah untuk memelihara keutuhan keluarga karena mempertimbangkan dampakdampak yang ditimbulkan oleh adanya perceraian.

\section{MODEL RESOLUSI KONFLIK PERKAWINAN MELALUI MEDIASI DALAM PERKARA PERCERAIAN}

Model resolusi konflik perkawinan melalui mediasi dalam perkara perceraian di Pengadilan Agama Manado adalah mediasi yang berfokus pada pendekatan konsensus para

pihak dengan bantuan mediator (Wawancara dengan Wakil Ketua Pengadilan Agama Manado).

Jenis mediasi yang paling sering digunakan di Pengadilan Agama Manado adalah penyelesaian sengketa perkawinan dengan bantuan mediator hakim, sedangkan mediator Non Hakim belum ada (Wawancara dengan Wakil Ketua Pengadilan Agama Manado).

Resolusi Konflik Perkawinan Melalui Mediasi Dalam Perkara Perceraian Di Pengadilan Agama Manado

Ridwan Jamal 
FAKTOR-FAKTOR KENDALA GAGALNYA RESOLUSI KONFLIK PERKAWINAN MELALUI MEDIASI DALAM PERKARA PERCERAIAN

Berdasarkan wawancara yang dilakukan terhadap informan penelitian, faktor-faktor kendala gagalnya resolusi konflik perkawinan melalui mediasi dalam perkara perceraian dapat dibagi dalam dua faktor kendala utama, yaitu: (1) kendala umum terdiri dari: faktor kaidah hukum, faktor keterbatasan jumlah hakim, faktor masyarakat yaitu rendahnya pengetahuan masyarakat, faktor sarana dan prasarana mediasi yang minim, dan faktor kebudayaan, dan (2) kendala khusus terdiri dari faktor penggugat, mediator, suasana mediasi, dan para pihak yang berperkara.

\section{KENDALA UMUM}

\section{FAKTOR KAIDAH HUKUM}

Berdasarkan wawancara yang dilakukan dengan informan, diperoleh informasi bahwa relatif sangat kecil kontribusi kegagalan resolusi konflik yang disebabkan oleh kaidah hukum yang ada sebab dari segi kaidah hukum telah secara jelas dan tegas diatur tentang prosedur dan tata cara mediasi di Pengadilan Agama. Hanya saja sanksi atau hukuman yang diberikan kepada para pihak yang tidak menempuh prosedur mediasi masih relatif ringan. Dalam Perma Nomor 1 Tahun 2008 hingga pembaharuannya yaitu Perma Nomor 1 Tahun 2016, sanksi yang diberikan bagi para pihak yang tidak menempuh mediasi yaitu dikenakan denda atau dibebankan biaya perkara. Akibatnya, para pihak yang bersengketa lebih terkadang lebih memilih membayar denda/biaya perkara yang jumlahnya tentu relatif kecil.

\section{FAKTOR KETERBATASAN JUMLAH HAKIM}

Berdasarkan observasi dan wawancara diketahui bahwa terdapat 6 hakim yang menjalankan tugas di Pengadilan Agama Manado yang terdiri atas Ketua Pengadilan Agama, Wakil Ketua Pengadilan Agama, dan 4 Hakim. Di dalam observasi ditemukan 1 ruang persidangan yang setiap hari dari senin sampai kamis dipakai untuk persidangan, maka 
berarti ada 1 majelis hakim yang bertugas yaitu 3 hakim yang menjalankan tugas, berarti tersisa 3 hakim. Dari 3 hakim ini salah satunya harus menjadi mediator pada sidang mediator, praktis tinggal 2 orang yang menjalankan fungsi organisasi Pengadilan Agama.

Dilihat dari jumlah kasus perkara perceraian untuk tahun 2015 saja yang mencapai 356 perkara, maka dalam 1 hari rata-rata di Pengadilan Agama Manado berlangsung lebih dari satu persidangan. Hal ini tentu belum termasuk agenda persidangan lainnya di luar perkara peceraian. Kondisi ini tentu tidak efektif karena jika terjadi suatu hal misalnya ada kunjungan keluar Pengadilan Agama atau ada salah satu saja hakim yang berhalangan hadir maka akan mengganggu tugas dalam menyelesaikan perkara setiap harinya.

Belum lagi jika melihat jumlah perkara perceraian yang ditangani Pengadilan Agama untuk tahun 2015 yaitu sebanyak 356, maka tugas hakim di luar proses persidangan sangatlah banyak, seperti diketahui bahwa tugas hakim bukan hanya berada dalam ruang persidangan akan tetapi juga membuat amar putusan. Meskipun kendala ini bukan merupakan kendala yang secara prosedur mempengaruhi perkara, akan tetapi secara teknis akan mengganggu Pengadilan Agama Manado secara organisasi. Sebagai solusi terkait jumlah hakim ini, hendaknya Mahkamah Agung dalam kebijakan mendistribusikan hakim harus proporsional sehinnga beban Pengadilan Agama tidak berat dalam menyelesaikan perkara. Sesuai dengan saran dari Wakil Ketua Pengadilan Agama Manado sebaiknya terdapat 10 hingga 12 hakim yang bertugas di Pengadilan Agama Manado.

Selain keterbatasan jumlah hakim, masalah kesungguhan para penegak hukum (hakim) untuk melaksanakan mediasi juga yang perlu ditingkatkan, pelaksanaan Perma Nomor 1 Tahun 2016 pengganti Perma Nomor 1 Tahun 2008, belum sepenuhnya diterapkan di Pengadilan Agama Manado seperti ketentuan dasar bagi pelaksana mediasi (mediator) non-hakim bersertifikat atau mediator hakim bersertifikat. Dalam ketentuan disebutkan bahwa mediasi dapat dilakukan oleh mediator non hakim yang mempunyai sertifikat bermediasi. Di Pengadilan Agama Manado, sejauh ini mediator hanya dilaksanakan oleh hakim. Demikian pula, masalah waktu mediasi terbatas dan hanya dilakukan di ruang 
mediasi. Penundaan sidang untuk proses mediasi masih ditentukan waktunya untuk menghindari pemanggilan ulang kembali para pihak padahal Peraturan Mahkamah Agung menghendaki agar diberi waktu seluas-luasnya para pihak untuk mediasi. Namun faktanya hal ini belum sepenuhnya diimplementasikan.

\section{FAKTOR MASYARAKAT}

Pengetahuan masyarakat tentang mediasi perceraian masih sangat minim sehingga para pihak cenderung tidak ingin menempuh proses mediasi (Wawancara dengan hakim mediasi di Pengadilan Agama Manado). Pada umumnya masyarakat belum memahami substansi Peraturan Mahkamah Agung RI tentang kewajiban para pihak untuk menempuh proses mediasi. Bahkan masyarakat masih beranggapan bahwa sejak pendaftaran perkara perceraian di Pengadilan Agama sudah menjustifikasi hasil para pihak untuk bercerai. Padahal semangat Peraturan Mahkamah Agung sejak dikeluarkannya SEMA Nomor 1 Tahun 2002, kemudian disempurnakan dengan Perma Nomor 2 Tahun 2003, kemudian direvisi dengan Perma Nomor 1 Tahun 2008 tanggal 31 Juli 2008 tentang Prosedur Mediasi, hingga yang revisi paling terbaru ialah Perma Nomor 1 Tahun 2016 tentang Prosedur Mediasi ialah ditemukannya solusi atau terjadinya resolusi konflik perkawinan sehingga para pihak yang berperkara cerai dapat diselesaikan dengan rujuk atau islah. Artinya, semangat Mahkamah Agung ialah perdamaian kedua belah pihak. Hal ini tentu menjadi komitmen Mahkamah Agung yang diimplementasikan secara operasional oleh Pengadilan Agama.

\section{FAKTOR SARANA DAN PRASARANA MEDIASI}

Sarana dan prasarana mediasi di Pengadilan Agama Manado masih sangat terbatas, apalagi bagi mediator hakim yang melaksanakan mediasi terbatas di ruang mediasi saja (Hasil observasi di Pengadilan Agama Manado). Berbeda dengan mediator non hakim dapat menempuh mediasi di mana saja yang dianggap representatif untuk bermediasi. 


\section{FAKTOR BUDAYA}

Masalah budaya sangat berpengaruh untuk keberhasilan mediasi, kebiasaan masyarakat yang sudah bersusah payah menghabiskan waktu, tenaga, dan materi untuk mendaftarkan perkaranya di Pengadilan Agama, sangat sulit mengurunkan niatnya untuk bercerai, terlebih lagi adanya faktor gengsi dan dorongan emosional diri dari pihak keluarga yang membesarkan-besarkan persoalan yang sepele.

Kebiasaan masyarakat menyelesaikan konflik perkawinan melalui gugatan cerai sering menjadi pilihan utama dan bukan pilihan terakhir yang perlu ditempuh oleh para pihak. Dampaknya ialah proses mediasi hanya menjadi prosedur formal hukum acara persidangan.

\section{FAKTOR PERBEDAAN PANDANGAN TERKAIT KETIDAKHADIRAN PARA PIHAK ATAU SEORANG PIHAK DALAM SIDANG PERTAMA KETIKA AKAN DIADAKANNYA MEDIASI}

Bahwa sengketa perwakinan (perceraian) yang diajukan ke Pengadilan tidak jarang saat hari persidangan yang telah ditentukan hanya dihadiri oleh satu pihak saja yaitu pihak Penggugat/Pemohon atau Tergugat/Termohon tidak diketahui alasan pastinya. Di sinilah sering muncul permasalahan, apakah persidangan ditunda untuk memanggil Tergugat/Termohon atau pihak yang tidak hadir sebagaimana pasal $127 \mathrm{HIR} / 151 \mathrm{RBg}$, atau ditunda untuk mediasi sesuai dengan Peraturan Mahkamah Agung Republik Indonesia Nomor 1 Tahun 2008. Di dalam berita yang dikeluarkan oleh Pengadilan Agama Manado terdapat fakta bahwa ada dua pandangan yang sementara ini muncul terhadap perkara ghoib atau perkara yang salah satu pihakya tidak hadir saat sidang yaitu: pertama, jika salah satu pihak tidak hadir pada saat sidang pertama, maka persidangan ditunda untuk memanggil ulang pihak yang tidak hadir sebagaimana ketentuan pasal $127 \mathrm{HIR} / 151 \mathrm{RBg}$ dan jika tetap tidak hadir, maka proses mediasi tidak dilakukan, begitu pula dalam hal perkara ghoib. Kedua, sidang ditunda untuk mediasi, terlepas apakah kedua belah pihak hadir saat sidang pertama atau hanya salah satu pihak saja yang hadir. Pandangan kelompok kedua ini 
didasari pada pasal 2 Ayat 3 dan Ayat 4 Peraturan Mahkamah Agung Republik Indonesia Nomor 1 Tahun 2008.

Di Pengadilan Agama Manado berdasarkan wawancara dengan Wakil Ketua Pengadilan Agama Manado terkait permasalahan ini para hakim cenderung condong pada pendapat kelompok pertama yaitu jika salah satu pihak tidak hadir, maka persidangan ditunda untuk memanggil ulang pihak yang tidak hadir dan jika tetap tidak hadir maka proses mediasi tidak dilakukan begitu pula dengan perkara ghoib. Kemudian di dalam amar putusanya disebutkan bahwa mediasi tidak layak dilakukan. Sebagai solusi dari uraian kendala hakim yang kedua ini maka hendaknya dibuat peraturan khusus tentang perkara ghoib ini sehingga tidak ada dua prosedur yang menjadi kerancuan dan kesulitan dari para hakim sendiri. Selain itu, agar terwujud tujuan hukum yaitu adanya kepastian hukum.

Penelitian terhadap hasil mediasi yang dilakukan di Pengadilan Agama Manado terkait keberhasilan mediasi dari tahun 2014 sebanyak 106 perkara yang dimediasi dan yang berhasil dimediasi hanya sebanyak 6 perkara, tahun 2015 sebanyak 102 perkara perceraian yang dimediasi dan hanya 4 perkara yang berhasil dimediasi, dan tahun 2016 (hingga bulan Oktober) sebanyak 97 perkara yang dimediasi dan hanya 3 perkara yang berhasil dimediasi. Menurut wakil ketua Pengadilan Agama Manado memang terkait mediasi perceraian sulit sekali untuk mediasi berhasil. Hal ini kata beliau karena menyangkut urusan hati. Jika hati sudah terkait maka akan sulit sekali untuk diobati.

Dilihat dari jumlah perkara yang dimediasi yaitu dari total 303 perkara perceraian sejak tahun 2014 hingga 2016 hanya terdapat 13 perkara yang berhasil dimediasi. Dari aspek efektivitas persidangan menjadi pertanyaan penting bila menilik diadakannya mediasi ini khususnya terkait perkara perceraian. Timbul suatu fenomena perlukah mediasi dalam perkara perceraian, hendaknya perlu dikaji kembali karena bukan hanya menyangkut sebab hak dan kewajiban, tetapi terkait juga masalah imateril berupa perasaan hati. Sementara itu, jika dilihat alasan Mahkamah Agung memberlakukan mediasi ini yaitu salah satunya 
terwujudnya peradilan yang cepat dan murah serta agar tidak terjadi penumpukan perkara dalam jumlah besar di Mahkamah Agung, maka dengan fakta yang ditemukan di dalam perkara perceraian tidak menunjukkan hal yang demikian dikarenakan proses mediasi yang berakhir dengan gagal berdamai.

Sebagai solusi dari uraian faktor kendala resolusi konflik dalam perkara perceraian yang ketiga di atas, maka harus dievaluasi kembali terkait pemberlakuan mediasi pada perkara perceraian karena terdapat kekhususan yang menyangkut juga permasalahan imateril berupa psikologis serta emosi dari para pihak. Perlu juga dipertimbangkan konsep BP4 yang pernah diterapkan, sehingga menurut pandangan peneliti jika syarat seorang melakukan perceraian harus melalui proses BP4 dahulu yang berada di Kantor Urusan Agama, maka akan semakin mempersulit seseorang untuk bercerai. Pada konteks ini diperlukan revitalisasi peran Kantor Urusan Agama sebagai lembaga yang berada pada tingkat kecamatan dan lebih dekat aksesnya terhadap masyarakat.

\section{BESARNYA BIAYA TERHADAP PROFESI MEDIATOR SELAIN HAKIM SERTA BATASAN TERHADAP HONOR YANG TIDAK JELAS}

Faktor yang menjadi penyebab enggannya para pihak untuk melakukan mediasi dengan dibantu oleh mediator selain hakim adalah biaya yang bertambah jika menggunakan mediator di luar hakim. Sementara untuk mediator hakim sendiri tidak ada penambahan biaya yang dibebankan pada para pihak, meskipun ada insentif yang diberikan bagi hakim yang berhasil menjalankan fungsi mediator seperti yang terdapat pada pasal 25 ayat 1 dan 2 Peraturan Mahkamah Agung Republik Indonesia Nomor 1 Tahun 2008 tentang proses mediasi di pengadilan yang menyatakan bahwa (1) Mahkamah Agung menyediakan sarana yang dibutuhkan bagi proses mediasi dan insentif bagi hakim yang berhasil menjalankan fungsi mediator dan (2) Mahkamah Agung menerbitkan perma tentang kriteria keberhasilan hakim dan insentif bagi hakim yang menjalankan fungsi mediator. Bagi mediator di luar hakim tidak ada batasan berapakah intentif dikenakan hanya disebutkan dalam pasal 10 
Peraturan Mahkamah Agung Republik Indonesia Nomor 1 Tahun 2008 tentang honorarium mediator ayat 2 bahwa uang jasa mediator bukan hakim ditanggung bersama oleh para pihak atau berdasarkan kesepakatan para pihak. Hal ini menjadi kendala jika terdapat kondisi dimana mediator hakim yang bertugas menjadi hakim jumlahnya terbatas seperti yang terdapat pada Pengadilan Agama Manado.

Sebagai solusi dari uraian faktor kendala yang keempat di atas maka penentuan tarif insentif ini hendaknya dibuat peraturan yang lebih rinci sehingga menjamin kepastian besarnya dana yang dibutuhkan dalam proses mediasi. Selain itu, niatan Mahkamah Agung untuk menghadirkan peradilan yang cepat dan murah harus diwujudkan dengan membuat peraturan tentang honor mediator non hakim.

\section{KENDALA KHUSUS}

Berdasarkan wawancara dengan informan penelitian, diketahui bahwa pada umumnya pihak penggugat ataupun tergugat sudah tidak menerima proses mediasi (Wawancara dengan Hakim Mediasi). Para penegak hukum telah mengikuti petunjuk Peraturan Mahkamah Agung untuk bermediasi, bahkan sebagai suatu keharusan yang telah tertuang dalam Berita Acara Sidang, sehingga dapat dipastikan setiap perkara yang dihadapi oleh para pihak di Pengadilan Agama Manado telah menempuh proses mediasi (Wawancara dengan Wakil Ketua Pengadilan Agama Manado). Selain itu, para penegak hukum sebenarnya telah memberi kesempatan kepada para pihak untuk memilih mediator sesuai dengan norma-norma mediator di Pengadilan Agama Manado. Dan, ada pihak yang langsung memilih mediatornya, namun umumnya hanya menyerahkan kepada majelis hakim untuk memilih mediator yang tersedia di Pengadilan Agama Manado (Wawancara dengan Wakil Ketua Pengadilan Agama Manado).

Berdasarkan observasi dan wawancara diketahui bahwa mediator di Pengadilan Agama Manado telah memiliki pengetahuan yang cukup membantu para pihak yang berperkara untuk menemukan solusi, meskipun belum semuanya pernah mengikuti atau 
menempuh pelatihan di tingkat pusat, tetapi kesemuanya telah berulang kali mengikuti pendidikan di tingkat propinsi/Pengadilan Tinggi Agama, terlebih lagi kegiatan lainnya seperti seminar, diskusi, simposium, dan kegiatan-kegiatan lainnya yang relevan dengan bidang tugas juga selalu diikuti oleh para penegak hukum terutama hakim mediator. Namun, pengetahuan hakim mediator yang memadai tidak cukup apabila tidak ditunjang oleh kesungguhan para pihak yang berperkara cerai untuk melakukan mediasi. Hal ini turut diperparah oleh pengetahuan masyarakat tentang mediasi masih sangat minim (Wawancara dengan Wakil Ketua Pengadilan Agama Manado).

\section{KENDALA KHUSUS LAINNYA}

Kendala khusus lainnya ialah pada umumnya mediasi dalam kasus cerai salah satu pihak pasif, bahkan pada banyak kasus kedua pihak yang berperkara cerai sudah sepakat untuk bercerai, sehingga keduanya pada umumnya bersikap pasif untuk menjalankan mediasi.

Di Pengadilan Agama Manado, sudah ada hakim yang bersertifikat, baik sertifikat yang dikeluarkan oleh Pengadilan Tinggi Agama, ataupun yang dikeluarkan oleh Mahkamah Agung RI. (Data Dokumen Diolah). Namun, mengigat jumlahnya yang masih terbatas sementara perkara yang ditangani cukup banyak, sehingga cenderung tidak efektif.

\section{KESIMPULAN}

Berdasarkan deskripsi temuan penelitian dan pembahasannya sebagaimana disajikan dalam Bab IV dapat dikemukakan kesimpulan penelitian sebagai berikut.

Pelaksanaan Resolusi Konflik Perkawinan Melalui Mediasi dalam Perkara Perceraian di Pengadilan Agama Manado dilakukan dengan mengikuti prosedur sebagaimana diatur dalam Peraturan Mahkamah Agung RI tentang Prosedur Mediasi di Pengadilan Agama yaitu mengacu pada Perma Nomor 1 Tahun 2008 dan telah diperbaharui dengan Perma Nomor 1 Tahun 2016 tentang Prosedur Mediasi. Tahap pelaksanaan resolusi konflik perkawinan 
melalui mediasi dalam perkara perceraian di Pengadilan Agama Manado ialah Pramediasi, Mediasi, dan Pascamediasi.

Model resolusi konflik perkawinan melalui mediasi dalam perkara perceraian di Pengadilan Agama Manado didasarkan pada konsensus oleh para pihak dengan dimediasi oleh mediator hakim, sedangkan mediator nonhakim belum dipraktekkan.

Faktor-faktor kendala gagalnya resolusi konflik perkawinan melalui mediasi dalam perkara perceraian di Pengadilan Agama Manado terdiri atas dua, yaitu kendala umum dan kendala khusus. Kendala umum, yaitu: Faktor kaidah hukum, jumlah hakim yang terbatas, faktor pengetahuan masyarakat tentang mediasi perceraian masih sangat minim sehingga para pihak cenderung tidak ingin menempuh proses mediasi,faktor sarana dan prasarana mediasi. Sarana dan prasarana mediasi di Pengadilan Agama Manado masih sangat terbatas, apalagi bagi mediator hakim yang melaksanakan mediasi terbatas di ruang mediasi saja, faktor budaya, terdapat dua pandangan yang dapat terjadi terkait ketidakhadiran para pihak atau seorang pihak dalam sidang pertama ketika akan diadakannya mediasi, faktor imateril, besarnya biaya terhadap profesi mediator selain hakim serta batasan terhadap honor yang tidak jelasSedangkan, kendala khusus ialah pada umumnya pihak penggugat ataupun tergugat sudah tidak menerima proses mediasi, kesungguhan para pihak yang berperkara cerai untuk melakukan mediasi, pada umumnya mediasi dalam kasus cerai salah satu pihak pasif, bahkan pada banyak kasus kedua pihak bersikap pasif untuk menjalankan mediasi, dan belum adanya pelaksana mediasi dari unsur non hakim.

\section{DAFTAR PUSTAKA}

'Alā' al-Dīn al-Ṭarablīsī, Mu'īn al-Hukkām, (t.th.). F̄̄ mā Yataraddad bayn al-Khasamayn min al-Ahkām. Bayrūt: Dār al-Fikr.

Al-Aynayni, Abu Muhammad Mahmud Ibn Ahmad, (t.th.). al-Bidãyah fi Syarh al-hidãyah, Jilid 9. Beirut: Dar al-Fikr.

Anogara, (1992). Psikologi Kerja. Jakarta: Rineka Cipta.

Dewi, Eva Meizara Puspita dan Basti, (2008). "Konflik Perkawinan Dan Model Penyelesaian Konflik Pada Pasangan Suami Istri”. Jurnal Psikologi Volume 2, No. 1, Desember 2008. 
E. Van Donzel, B. Lewis, dkk. (ed), (1990). Encyclopedia of Islam, Jilid. IV. Leiden: E.J. Brill.

Fisher, Simon, et al. (2001). Mengelola Konflik, Keterampilan dan Strategi untuk Bertindak. Jakarta: The British Council.

Goodpaster, (1993). Negosiasi dan Mediasi: Sebuah Pedoman Negosiasi dan Penyelesaian Sengketa Melalui Negosiasi. Jakarta: ELIPS Project.

Hardiyanti, Okky Putri, dkk., (2014). "Efektivitas Pelaksanaan Mediasi Dalam Perkara Perceraian Di Pengadilan Agama Kota Malang”. Universitas Brawijaya. Online: Tersedia pada http://www. .portalgaruda.org/

Jannah, Tiara Miftahul, (2013). "Mediasi di dalam Perkara Perceraian yang Dilakukan Hakim Pengadilan Agama". E-Jurnal Gloria Yuris Prodi Ilmu Hukum Universitas Tanjungpura, Vol 1, No 3 (2013): JURNAL MAHASISWA S1 FAKULTAS HUKUM UNTAN. Online: Tersedia pada http://jurnal.untan.ac.id/index.php/jmfh/article/view/3227

Kartono, K., (1992). Psikologi Wanita: Mengenal Gadis Remaja dan Wanita Dewasa, Jilid I. Bandung: PT. Mandar Maju.

Kartono, K., (1992). Psikologi Wanita: Mengenal Gadis Remaja dan Wanita Dewasa, Jilid II; Bandung: PT. Mandar Maju.

Levine, Stewart, (1998). Getting to Resolution (Turning Conflict into Collaboration). San Fransisco: Berrett Koehler Publishers Inc.

Luney, Percy R., Jr, (1989). "Traditions an Foreign Influences: Systems of Law in China and Japan,"dalam Law and Contemporary Problems, Vol. 52, No. 2 (Spring 1989).

Mindes, Gayle, (2006). Teaching Young Children Social Studies. United States of America: Praeger Publishers.

Moleong, Lexy J. (2013). Metodologi Penelitian Kualitatif. Edisi Revisi. Bandung: PT Remaja Rosdakarya.

Morton, Deutsch and Coleman, Peter T., (2006). The Handbook of Conflict Resolution, Theory and Practice. San Fransisco: Jossey-Bass Publisher.

Prastyo, Ari Adnan, dkk. 2013. "Kendala yang Dihadapi Hakim dalam Pelaksanaan Mediasi Perceraian di Pengadilan Agama Sragen”. Jurnal PARENTAL Vol. 1, No 2 (2013) Online: Tersedia pada http://jurnal. hukum.uns.ac.id/index.php/parental/article/view/425

Sears, D.O., Freedman, J.L., and Peplau, L.A., (1985). Psikologi sosial. Jakarta: Erlangga.

Slamet, Abidin, dkk., (1999). Fiqh Munakahat. Bandung: Pustaka Setia.

Usman, Rachmadi, (2012). Mediasi di Pengadilan dalam Teori dan Praktik. Jakarta: Sinar Grafika.

\section{Dokumen Resmi:}

Perma RI Nomor 1 Tahun 2008 tentang Prosedur Mediasi

Perma RI Nomor 1 Tahun 2016 tentang Prosedur Mediasi

Perma RI Nomor 2 Tahun 2003 tentang Prosedur Mediasi

Perma RI Nomor 7 Tahun 2015 tentang Organisasi dan Tata Kerja Kepaniteraan dan Kesekretariatan Peradilan

Sema Nomor 1 Tahun 2002.

Undang-Undang Nomor 1 Tahun 1974 tentang Perkawinan

Undang-Undang Nomor 3 Tahun 2006 tentang Peradilan Agama

Undang-Undang Nomor 50 Tahun 2009 tentang Perubahan Kedua Atas Undang-undang Nomor 7 Tahun 1989 tentang Peradilan Agama

$\overline{\text { Resolusi Konflik Perkawinan Melalui Mediasi Dalam Perkara Perceraian Di Pengadilan }}$ Agama Manado

Ridwan Jamal 
Jurnal Ilmiah Al-Syir'ah Vol. 15 No. 2 Tahun 2017

Institut Agama Islam Negeri (IAIN Manado)

Undang-Undang Nomor 7 Tahun 1989 tentang Peradilan Agama

Resolusi Konflik Perkawinan Melalui Mediasi Dalam Perkara Perceraian Di Pengadilan Agama Manado

Ridwan Jamal 